\title{
Effect of Different Solutions on Knoop Hardness of Indirect Composite Resins
}

\author{
dos Santos DM*, Massurani L, Goiato MC, Zavanelli AC, Haddad MF, Moreno A and Vechiato-Filho AJ \\ Department of Dental Materials and Prosthodontics, Araçatuba Dental School, Univ Estadual Paulista - UNESP, Araçatuba, São Paulo, Brazil
}

\begin{abstract}
Introduction: Indirect dental composites may have adequate clinical performance. However, the literature is scarce regarding indirect composite resins and these solutions should be considered to maintain their properties. The aim of the study was to evaluate the influence of beverages, mouthwashes and bleaching agents on the hardness of indirect composite resins.

Methods: Five different brands of indirect composite resins were evaluated: Adoro, Resilab, Cristobal, Sinfony and Epricord. Ten specimens of each brand were immersed in eleven different solutions: four mouthwashes (Listerine, Oral-B, Plax, Periogard), four beverages (coke soft drink, red wine, coffee, orange juice), three dental bleaching agents ( $16 \%$ peroxide of carbamide, $7.5 \%$ and $38 \%$ peroxide of hydrogen) and artificial saliva (control group). The Knoop hardness was measured before (baseline) and after 12, 24, 36 and 60 hours of immersion in mouthwashes; after 7, 14 and 21 days of immersion in beverages and after 7 and 14 days of immersion in dental bleaching agents. The results were analyzed using 3-way repeated measures ANOVA and Tukey's test $(p<0.05)$.

Results: All resins presented significant decrease on hardness values after immersion process whereas this reduction was higher for Resilab and Sinfony. The latter exhibited the lowest initial values of hardness while Cristobol resin presented the highest hardness values. The mouthwashes promoted a significant decrease in the hardness of specimens.
\end{abstract}

Keywords: Hardness; Food; Dental materials; Hydrogen peroxide; Oral hygiene

\section{Introduction}

Indirect composite systems were introduced as an alternative to problems related to ceramic and direct composite restorations [1,2]. These indirect composites present high density of ceramic particles and alterations in their resin matrix [3]. Some of their properties such as the ability to strengthen a weakened tooth, great aesthetics, important physical properties and easy manipulation increase their popularity in dentistry market [4].

Indirect dental composites may have adequate clinical performance but it is extremely important to evaluate their physical and mechanical properties in high stress situations. An alteration of these properties might create micro-cracks in the restorations, loss of surface gloss, bacterial adhesion and color alteration leading the restorative treatment to failure $[5,6]$. The water absorption, the size and distribution of the inorganic particles as well as the consumption of common beverages may affect these properties, decreasing their hardness and facilitating the wear of their surfaces with the course of time [3].

There are studies that evaluated the water sorption in intraoral environment and the effect of common beverages and bleaching agents on the mechanical properties of direct composites [7-11]. However, the literature is scarce regarding indirect composite resins and these solutions should be considered to maintain their properties.

The aim of the study was to evaluate the effects of common beverages, mouthwashes and bleaching agents on the hardness of indirect composite resins. The hypothesis of this study was that the hardness of these composites is affected by the storage period and the solution.

\section{Materials and Methods}

Five different brands of indirect composite resins on B2 shade color were evaluated (Table 1). Sixty hundred specimens were fabricated. Ten specimens of each brand were immersed in eleven different solutions and artificial saliva (control group). The composition of the saliva was $\mathrm{KCl}\left(0.4 \mathrm{~g} \mathrm{~L}^{-1}\right), \mathrm{NaCl}\left(0.4 \mathrm{~g} \mathrm{~L}^{-1}\right), \mathrm{CaCl}_{2 \cdot 2} \mathrm{H}_{2} \mathrm{O}\left(0.906 \mathrm{~g} \mathrm{~L}^{-1}\right), \mathrm{NaH}_{2} \mathrm{PO}_{4 \cdot 2} \mathrm{H}_{2} \mathrm{O}$ $\left(0.690 \mathrm{~g} \mathrm{~L}^{-1}\right), \mathrm{Na}_{2} \mathrm{~S}_{9} \mathrm{H}_{2} \mathrm{O}\left(0.005 \mathrm{~g} \mathrm{~L}^{-1}\right)$, and urea $\left(1 \mathrm{~g} \mathrm{~L}^{-1}\right)[12]$.

The specimens were fabricated by a metallic matrix $(10 \mathrm{~mm} \times 5$ $\mathrm{mm} \times 1.5 \mathrm{~mm}$ ). The matrix consisted of an upper and a lower part. The latter was placed on a glass surface and filled with one of the test indirect composite resins. After, another glass plate was positioned over the resin layer to drain the excess of the material maintaining its surface smooth and homogeneous. The specimen was curried according to the manufacturer's instructions [13]. Subsequently, the upper part of the matrix was positioned over the lower part and it was filled with composite resin similarly to the first preparation stage. The matrix was carefully removed and the specimen was final curried according to the instructions of manufacturers.

After, specimens were sequentially polished with 240-, 400-, 800and 1200-grit sandpaper (CarbiMet 2; Buehler, Lake Bluff, IL) in a semi-automatic polisher (Ecomet 300PRO, Buehler, Illinois, EUA). The procedure with the polishing machine was followed by the use of a polishing cloth (TexMet Polishing Cloth; Buehler) and a diamond paste (9-micron, MetaDi; Buehler). The thickness of each specimen was

*Corresponding author: Daniela Micheline dos Santos, Araçatuba Dental School, Univ Estadual Paulista - UNESP, Department of Dental Materials and Prosthodontics, Street: José Bonifácio, 1193 - Vila Mendonça, CEP 16015050 Araçatuba, São Paulo, Brazil, Tel: 55-18-3636-3287; Fax: 55-18-36363245; E-mail: danielamicheline@foa.unesp.br

Received January 03, 2014; Accepted February 03, 2014; Published February 05, 2014

Citation: dos Santos DM, Massurani L, Goiato MC, Zavanelli AC, Haddad MF, et al. (2014) Effect of Different Solutions on Knoop Hardness of Indirect Composite Resins. Dentistry 4: 208. doi:10.4172/2161-1122.1000208

Copyright: (C) 2014 dos Santos DM, et al. This is an open-access article distributed under the terms of the Creative Commons Attribution License, which permits unrestricted use, distribution, and reproduction in any medium, provided the original author and source are credited. 


\begin{tabular}{|c|c|c|}
\hline Comercial Brand & Manufacturer & Chemical Composition \\
\hline Adoro & $\begin{array}{l}\text { IvoclarVivadent Ltda., São } \\
\text { Paulo, São Paulo, Brazil. }\end{array}$ & $\begin{array}{c}17 \text { to } 19 \% \text { of dimethacrylate, } 82 \text { to } 83 \% \text { of } \\
\text { copolymers of silicon oxide and } 1 \% \text { of stabilizers, } \\
\text { catalysts and pigments. }\end{array}$ \\
\hline Resilab Master & $\begin{array}{l}\text { Wilcos do Brasil, Industria e } \\
\text { Comércio Ltda. Petrópolis, } \\
\text { Rio de Janeiro, Brazil. }\end{array}$ & $\begin{array}{l}\text { Small particles with mean size of } 0.05 \mathrm{~mm}, 53 \% \\
\text { of ceramic filler particles, BISGMA, BIGEMA, } \\
\text { UDMA, TEGMA, } \\
\text { Aluminum borosilicate, highly dispersible silicon } \\
\text { acid, photo initiators, inhibitors and pigments. }\end{array}$ \\
\hline Cristobal & $\begin{array}{l}\text { DentisplyCeramco, } \\
\text { Burlington, New Jersey, } \\
\text { USA. }\end{array}$ & $\begin{array}{c}74 \% \text { of inorganic particles of pyrogenic silica, } \\
\text { barium glass and borosilicate. }\end{array}$ \\
\hline Sinfony & $\begin{array}{l}\text { 3M ESPE, Campinas, São } \\
\text { Paulo, Brazil. }\end{array}$ & $\begin{array}{c}48 \% \text { of resin matrix (UDMA), } 40 \% \text { of strontium } \\
\text { glass (macro particle of } 0.6 \mu \mathrm{m} \text { ), } 5 \% \text { pyrogenic } \\
\text { silica (micro particle of } 0.06 \mu \mathrm{m} \text { ), } 5 \% \text { of glass } \\
\text { ionomer cement particles, } 1 \% \text { silane and } 1 \% \\
\text { initiator. }\end{array}$ \\
\hline Epricord & $\begin{array}{c}\text { Kuraray Medical Inc, Tokyo, } \\
\text { Japan. }\end{array}$ & $\begin{array}{l}53 \% \text { ceramic filler content, } 25 \% \text { of multifunctional } \\
\text { polymers, } 22 \% \text { of conventional resins photo } \\
\text { initiators. The mean particle size is } 0.6 \mu \mathrm{m} \text {. }\end{array}$ \\
\hline
\end{tabular}

\section{Initial curing procedure in Targis Quick pre-curing with halogen lamp (intensity of $600 \mathrm{~mW} / \mathrm{cm}^{2}$ ). Then, the resin must be involved with glycerin gel and cured in the Lunamat 100 curing unit. Eight lamps emit a fluorescent light in mirrored environment for 25 minutes $\left(10\right.$ minutes with light, 10 with heat at $1040^{\circ} \mathrm{C}$ and 5 minutes with cooling of the curing unit. The potency hits $750 \mathrm{~W}$.}

Initial curing procedures for 4 minutes in EDG-Lux curing unit (400$500 \mathrm{~mW} / \mathrm{cm}^{2}$ ) with maximum temperature not exceeding $50^{\circ} \mathrm{C}$. Final curing for 8 minutes in EDG-Lux curing unit (400 -500 mW/ $\mathrm{cm}^{2}$ ).

Pre-curing in Mpa2000 curing unit for 90 seconds $\left(200 \mathrm{~mW} / \mathrm{cm}^{2}\right)$ in a first stage and then for 75 seconds $\left(800-1000 \mathrm{~mW} / \mathrm{cm}^{2}\right)$ in a second stage. Final curing in Post Cure unit for 8 minutes at $80^{\circ} \mathrm{C}$.

Pre-curing for 15 seconds in Visio Alfa Light and Visio Beta VarioLigth curing unit associated with Visio Beta Vacuum pump $\left(470 \mathrm{~mW} / \mathrm{cm}^{2}\right)$. Final curing in two stages: 1 minute of light emission followed by 14 minutes of light emission in vaccum in Visio Beta.

Precuring for 30 seconds in Kota curing unit. Final curing for 180 seconds with halogen lamp $\left(600 \mathrm{~mW} / \mathrm{cm}^{2}\right)$ in Kota curing unit.

Table 1: Indirect composite resins evaluated.

\begin{tabular}{|c|c|c|c|c|c|}
\hline Variation factors & $d f$ & SS & MS & $\mathbf{F}$ & $P$ \\
\hline Resin & 4 & 92855.04 & 23213.76 & 1181.17 & $<0.001^{*}$ \\
\hline Common Beverage & 4 & 185.66 & 46.41 & 2.36 & 0.054 \\
\hline Resin $\times$ common beverage & 16 & 1352.73 & 84.55 & 4.30 & $<0.001^{*}$ \\
\hline Between samples & 225 & 4421.95 & 19.65 & & \\
\hline Period & 3 & 13026.15 & 4342.05 & 2369.04 & $<0.001^{*}$ \\
\hline Period $\times$ resin & 12 & 2002.01 & 166.83 & 91.03 & $<0.001^{*}$ \\
\hline Period $\times$ common beverage & 12 & 136.65 & 11.39 & 6.21 & $<0.001^{*}$ \\
\hline Period $\times$ resin $\times$ common beverage & 48 & 731.75 & 15.24 & 8.32 & $<0.001^{*}$ \\
\hline Intra samples & 675 & 1237.16 & 1.83 & & \\
\hline
\end{tabular}

${ }^{*} P<.05$ indicates statistically significant difference.

Table 2: Three-way repeated-measures analysis of variance (ANOVA) for common beverages.

measured with a digital caliper (500-171-20B, Mitutoyo, Tokyo, Japan) to obtain the proposed dimensions.

All the specimens were stored in distilled water at $37 \pm 1^{\circ} \mathrm{C}$ (CIENLAB Equipamentos Cientificos Ltda, Campinas, Sao Paulo, Brazil) for 24 hours before hardness test [14-17].The Knoop hardness was determined using a hardness tester (HMV-2T; Shimadzu Corp., Kyoto, Japan) applying a 25g load for 10 seconds [11]. Then, the specimens were immersed in one of 11 test solutions: Listerine (Johnson \& Johnson Ltda, São José dos Campos, São Paulo, Brazil), Oral B (Eurofarma Laboratórios Ltda, Itapevi, São Paulo, Brazil), Colgate Plax (Colgate-Palmolive Ldta, São Bernardo dos Campos, São Paulo, Brazil), Colgate PerioGard (Colgate-Palmolive Ldta, São Bernardo dos Campos, São Paulo, Brazil), coke soft drink (Coca-Cola, Cia de Bebidas Ipiranga, Indústria Brasileira de Bebida, Ribeirão Preto, São Paulo, Brazil), red wine (José Maria Da Fonseca Vinhos S.A, Azeitão, Portugal), coffee (Sara Lee Cafés do Brazil Ltda, Jundiaí, São Paulo, Brazil), orange juice (Coca-Cola, Cia de Bebidas Ipiranga, Indústria Brasileira de Bebida, Ribeirão Preto, São Paulo, Brazil) and three bleaching agents: $16 \%$ carbamide peroxide (FGM Produtos Odontológicos, Joinville, Santa Catarina, Brazil), $7.5 \%$ and $38 \%$ hydrogen peroxide (FGM Produtos Odontológicos, Joinville, Santa Catarina, Brazil). Ten specimens were immersed in artificial saliva (Farmácia de Manipulação Apothicário, Araçatuba, São Paulo, Brazil) as a control.

The specimens immersed in mouthwashes were stored in an incubator at $37 \pm 1^{\circ} \mathrm{C}$ for 60 hours. The hardness test was performed after 12, 24, 36 and 60 hours. Sixty hours of immersion simulate the use of mouthwashes twice a day, during two minutes for five years [14]. The immersion process in the beverages was performed during 4 hours a day at $37 \pm 1^{\circ} \mathrm{C}$ for 21 days. The specimens were stored in artificial saliva while they were not immersed in their respective beverages. The hardness test was determined after 7, 14 and 21 days of immersion. According to Guler et al., 24 hours of storage simulate the consumption of coffee for one month [15].

The specimens in bleaching agents were stored fortwo hours in $16 \%$ carbamide peroxide [16], two hours in $7.5 \%$ hydrogen $\mathrm{n}$ peroxide and for 40 minutes in $38 \%$ hydrogen peroxide per day during 14 days. The immersion process in bleaching agents was conducted at $37 \pm 1^{\circ} \mathrm{C}$ for 14 days. Then, the specimens were stored in artificial saliva [16]. The hardness test was performed after 7 and 14 days of immersion.

After each period of immersion in the mouthwashes, beverages and bleaching agents, the Knoop hardness test was repeated. The solutions were replaced after each period of immersion. The authors verified visible color alterations after the immersion in all the tested solutions although the color change was not the purpose of this study. The specimens immersed in the mouthwashes became more greenish, the specimens immersed in the beverages became more darkened and the specimens immersed in the bleaching agents became brighter.

A three-way repeated-measures analysis of variance (ANOVA) was performed to identify significant differences among the resins, the solutions used, and immersion period. The Tukey-Kramer HSD test was used for post-hoc analysis. All data were analyzed at a significance level of 0.05 . 


\section{Results}

There were significant differences among the immersion period, resins and the solutions used (mouthwashes, beverages and bleaching agents). However, only the mouthwashes affected significantly the hardness of indirect composite resins regardless the resins and immersion period comparing them with other solutions (Tables 2-4).

The Sinfony resin exhibited the lowest initial values of hardness while Cristobol resin presented the highest initial values of hardness (Tables 5-7).

All resins presented significant decrease on hardness values along the immersion in the different solutions whereas this reduction was higher for Resilab and Sinfony (Tables 4, 5 and 7).

\section{Discussion}

The hypothesis of the study was accepted because among the evaluated factors, only the mouthwashes and immersion period affected significantly the hardness of the specimens.

The beverages and the bleaching agents may not have affected the hardness because of the polish and finishing processes that removed the instable layer of the resin enhancing the resistance to chemical solutions [17]. However, this fact did not occur with mouthwashes whereas these solutions affected the hardness of the resins. The decrease of hardness may be attributed to the intention of simulating two years of patient's hygiene habits, leading to a continuous storage of the specimens. Thus, the specimens were in direct contact with the alcohol content of the mouthwashes which might soften the resins affecting the adhesion of their filler particles to the matrix resins and leading the surface more susceptible to degradation $[7,18]$. Festuccia et al. affirmed that even with no alcoholic content, the alcohol-free mouthwashes have phosphoric acid in its composition which can damage the resin affecting the longevity of composite restorations [18].

\begin{tabular}{|c|c|c|c|c|c|}
\hline \multirow{2}{*}{ Resin } & \multirow{2}{*}{ Common beverages } & \multicolumn{4}{|c|}{ Period } \\
\hline & & Inital & After 7 days & After 14 days & After 21 days \\
\hline \multirow[t]{5}{*}{ Adoro } & Saliva & $43.00(3.13) \mathrm{Aa}$ & $42.13(4.08) \mathrm{Aa}$ & $39.24(4.75) \mathrm{Aa}$ & 38.70 (4.49) Aa \\
\hline & Coke & $42.73(2.57) \mathrm{Aa}$ & 39.33 (1.24) Aab & 36.41 (1.92) ABCb & $35.87(2.17) \mathrm{ABCb}$ \\
\hline & Wine & 42.62 (2.40) Aa & 39.97 (1.92) Aa & 31.79 (1.11) BCb & 31.38 (1.67) BCb \\
\hline & Coffe & $43.57(1.93) \mathrm{Aa}$ & $40.28(2.10) \mathrm{Aa}$ & $33.88(1.20) \mathrm{Bb}$ & 33.16 (1.19) Bb \\
\hline & Juice & 42.59 (2.22) Aa & $40.84(3.20) \mathrm{Aa}$ & $38.43(1.31) \mathrm{ABa}$ & 37.85 (1.11) ABa \\
\hline \multirow[t]{5}{*}{ Resilab } & Saliva & 42.08 (3.57) Aa & $28.94(3.50) \mathrm{Ab}$ & $28.45(4.48) \mathrm{ABb}$ & $24.82(3.30) \mathrm{Ab}$ \\
\hline & Coke & $42.25(2.25) \mathrm{Aa}$ & $31.17(3.71) \mathrm{ABb}$ & 28.24 (4.92) Abc & $25.61(4.34) \mathrm{Ac}$ \\
\hline & Wine & $42.28(2.72) \mathrm{Aa}$ & 29.61 (3.97) Ab & 29.97 (3.75) ABb & 28.38 (3.51) Ab \\
\hline & Coffe & $42.66(2.69) \mathrm{Aa}$ & 29.24 (3.44) Ab & $28.43(2.20) \mathrm{ABb}$ & 26.16 (2.96) Ab \\
\hline & Juice & $44.58(3.56) \mathrm{Aa}$ & $34.89(5.63) \mathrm{Bb}$ & 33.12 (6.13) Bbc & $28.54(3.47) \mathrm{Ac}$ \\
\hline \multirow[t]{5}{*}{ Cristobol } & Saliva & $48.82(1.97) \mathrm{Aa}$ & 46.07 (1.38) Aab & $43.83(1.41) \mathrm{Ab}$ & 41.56 (1.62) Ab \\
\hline & Coke & $48.36(1.08) \mathrm{Aa}$ & $42.81(0.60) \mathrm{ABb}$ & 39.43 (1.05) ABb & $38.28(0.60) \mathrm{Ab}$ \\
\hline & Wine & $47.82(1.04) \mathrm{Aa}$ & 44.37 (1.94) Aab & $42.95(2.16) \mathrm{Ab}$ & $42.24(2.60) \mathrm{Ab}$ \\
\hline & Coffe & $47.92(0.38) \mathrm{Aa}$ & $39.19(0.37) \mathrm{Bb}$ & $37.80(0.55) \mathrm{Bb}$ & $39.16(1.84) \mathrm{Ab}$ \\
\hline & Juice & $48.26(0.48) \mathrm{Aa}$ & 43.42 (1.29) ABb & 40.32 (1.34) ABb & 39.42 (1.97) Ab \\
\hline \multirow[t]{5}{*}{ Sinfony } & Saliva & $21.15(3.79) \mathrm{Aa}$ & 13.65 (3.98) Ab & $12.35(2.86) \mathrm{Ab}$ & 11.37 (3.67) Ab \\
\hline & Coke & $20.16(1.73) \mathrm{Aa}$ & 15.28 (2.08) Ab & $13.83(2.33) \mathrm{Ab}$ & $13.72(2.54) \mathrm{Ab}$ \\
\hline & Wine & $20.76(1.16) \mathrm{Aa}$ & 14.87 (2.36) Ab & $13.36(2.65) \mathrm{Ab}$ & 12.91 (2.66) Ab \\
\hline & Coffe & 19.99 (1.49) Aa & 13.56 (1.53) Ab & $13.50(1.51) \mathrm{Ab}$ & 12.05 (1.56) Ab \\
\hline & Juice & $20.05(0.91) \mathrm{Aa}$ & $13.62(1.18) \mathrm{Ab}$ & 12.33 (1.30) Ab & $11.11(2.48) \mathrm{Ab}$ \\
\hline \multirow[t]{5}{*}{ Epricord } & Saliva & $38.96(0.82) \mathrm{Aa}$ & 34.95 (0.82) Aab & 34.71 (1.60) Aab & $33.10(0.79) \mathrm{ABb}$ \\
\hline & Coke & 40.24 (1.38) Aa & 34.16 (2.15) Ab & $32.12(2.84) \mathrm{Ab}$ & 31.03 (2.66) ABb \\
\hline & Wine & $39.38(0.95) \mathrm{Aa}$ & 34.82 (2.25) Aab & $34.02(2.18) \mathrm{Ab}$ & 35.85 (1.80) Aab \\
\hline & Coffe & $40.70(0.73) \mathrm{Aa}$ & $35.36(1.20) \mathrm{Ab}$ & $34.71(1.27) \mathrm{Ab}$ & $33.97(0.94) \mathrm{ABb}$ \\
\hline & Juice & $39.62(0.29) \mathrm{Aa}$ & $34.19(1.91) \mathrm{Ab}$ & $32.07(1.54) \mathrm{Ab}$ & $30.61(1.80) \mathrm{Bb}$ \\
\hline
\end{tabular}

Means followed by the same uppercase letter in the column (comparison of each resin brand) and the same lowercase letter in the line does not differ to $5 \%$ level of significance $(P<.05)$ in Tukey's test.

Table 3: Mean results (Standard Deviation) of Knoop hardness of indirect composite resins for common beverages.

\begin{tabular}{|c|c|c|c|c|c|}
\hline Variation factors & $d f$ & SS & MS & $\mathbf{F}$ & $P$ \\
\hline Resin & 4 & 120522.51 & 30130.63 & 782.58 & $<0,001^{*}$ \\
\hline Mouthwash & 4 & 2918.14 & 729.53 & 18.95 & $<0,001^{*}$ \\
\hline Resin $x$ mouthwash & 16 & 1070.29 & 66.89 & 1.74 & $0.041^{*}$ \\
\hline Between samples & 225 & 8662.83 & 38.50 & & \\
\hline Period & 4 & 19070.18 & 4767.55 & 1932.05 & $<0,001^{*}$ \\
\hline Period $x$ resin & 16 & 707.45 & 44.22 & 17.92 & $<0,001^{*}$ \\
\hline Period $x$ mouthwash & 16 & 854.01 & 53.38 & 21.63 & $<0.001^{*}$ \\
\hline Period $\mathrm{x}$ resin $\mathrm{x}$ mouthwash & 64 & 572.12 & 8.94 & 3.62 & $<0.001^{*}$ \\
\hline Intra samples & 900 & 2220.85 & 2.47 & & \\
\hline
\end{tabular}

${ }^{*} \mathrm{P}<.05$ indicates statistically significant difference.

Table 4: Three-way repeated-measures analysis of variance (ANOVA) for mouthwashes. 


\begin{tabular}{|c|c|c|c|c|c|c|}
\hline \multirow{2}{*}{ Resin } & \multirow{2}{*}{ Solution } & \multicolumn{5}{|c|}{ Period } \\
\hline & & Inital & 12 hours & 24 hours & 36 hours & 60 hours \\
\hline \multirow[t]{5}{*}{ Adoro } & Saliva & 43.00 (3.13) Aa & 40.06 (4.00) Aab & 37.36 (5.62) Aab & 37.13 (4.62) Aab & $35.82(4.60) \mathrm{Ab}$ \\
\hline & Listerine & $43.20(2.88) \mathrm{Aa}$ & $34.80(4.34) \mathrm{Ab}$ & $33.39(4.30) \mathrm{Ab}$ & $32.02(2.56) \mathrm{Ab}$ & $29.76(2.30) \mathrm{Ab}$ \\
\hline & Oral-B & $42.62(0.91) \mathrm{Aa}$ & 39.03 (4.38) Aab & $36.04(4.60) \mathrm{Ab}$ & 35.06 (5.07) Ab & 33.65 (5.76) Ab \\
\hline & Plax & 42.87 (1.54) Aa & 36.63 (3.34) Ab & 33.71 (2.99) Abc & 31.10 (2.42) Abc & $30.14(1.72) \mathrm{Ac}$ \\
\hline & Periogard & $42.71(1.31) \mathrm{Aa}$ & 37.61 (3.73) Aab & $34.88(2.92) \mathrm{Ab}$ & 34.25 (2.73) Ab & $31.63(3.28) \mathrm{Ab}$ \\
\hline \multirow[t]{5}{*}{ Resilab } & Saliva & 42.08 (3.57) Aa & 36.60 (5.28) Aab & $35.87(5.03) \mathrm{Ab}$ & $33.82(4.23) \mathrm{Ab}$ & $31.08(3.63) \mathrm{Ab}$ \\
\hline & Listerine & 42.54 (3.88) Aa & $31.63(5.36) \mathrm{Ab}$ & $30.53(4.41) \mathrm{Ab}$ & 28.06 (3.77) Abc & $24.33(4.31) \mathrm{Bc}$ \\
\hline & Oral-B & $41.97(2.25) \mathrm{Aa}$ & $34.04(3.20) \mathrm{Ab}$ & 33.05 (3.45) Ab & 31.39 (2.95) Ab & $28.43(4.20) \mathrm{ABb}$ \\
\hline & Plax & $43.76(3.84) \mathrm{Aa}$ & 35.07 (4.75) Ab & $33.90(4.59) \mathrm{Ab}$ & $32.33(3.80) \mathrm{Ab}$ & $30.00(3.65) \mathrm{ABb}$ \\
\hline & Periogard & 42.30 (3.45) Aa & $33.29(3.52) \mathrm{Ab}$ & $32.52(3.34) \mathrm{Ab}$ & 31.11 (3.09) Ab & $30.71(3.34) \mathrm{Ab}$ \\
\hline \multirow[t]{5}{*}{ Cristobol } & Saliva & 48.82 (1.97) Aa & $47.79(2.21) \mathrm{Aa}$ & 45.89 (1.56) Aab & 43.06 (1.87) Aab & $40.31(1.01) \mathrm{Ab}$ \\
\hline & Listerine & $48.16(2.49) \mathrm{Aa}$ & 41.98 (1.38) Ab & 38.34 (1.32) Bbc & 36.79 (1.17) Bbc & $32.94(0.91) \mathrm{Bc}$ \\
\hline & Oral-B & 48.72 (2.29) Aab & $47.00(2.39) \mathrm{Aa}$ & 41.22 (1.77) ABac & 39.12 (1.19) Abc & 36.35 (1.12) Abc \\
\hline & Plax & $48.08(0.92) \mathrm{Aa}$ & $46.93(0.54)$ Aab & 45.19 (1.86) Aab & 41.33 (2.96) ABb & 38.95 (2.78)ABbc \\
\hline & Periogard & 49.18 (3.18) Aa & 44.38 (2.11) Aab & 42.83 (1.93) ABb & 39.89 (3.10) ABb & 37.15 (3.40)ABbc \\
\hline \multirow[t]{5}{*}{ Sinfony } & Saliva & 21.15 (3.79) Aa & 19.66 (6.45) Aab & 17.73 (5.58) Aab & $14.72(5.10) \mathrm{Ab}$ & 12.95 (4.74) Abc \\
\hline & Listerine & $19.97(1.46) \mathrm{Aa}$ & 7.51 (1.87) BCb & $6.71(1.23) \mathrm{BCb}$ & $6.83(1.42) \mathrm{Bb}$ & $5.37(1.06) \mathrm{Bb}$ \\
\hline & Oral-B & $20.12(0.75) \mathrm{Aa}$ & 14.76 (0.90) ACab & 14.02 (1.28) ACab & $12.40(0.88) \mathrm{ABb}$ & $11.37(0.69) \mathrm{ABb}$ \\
\hline & Plax & $19.86(2.14) \mathrm{Aa}$ & 13.73 (4.86) ACb & $13.51(4.11) \mathrm{ACb}$ & 12.55 (3.89) ABb & $11.25(3.04) \mathrm{ABb}$ \\
\hline & Periogard & 20.52 (1.22) Aa & $11.29(1.57) \mathrm{Cb}$ & $10.56(1.22) \mathrm{Cb}$ & $10.39(0.91) \mathrm{ABb}$ & $9.62(0.48) \mathrm{ABb}$ \\
\hline \multirow[t]{5}{*}{ Epricord } & Saliva & $38.96(0.82) \mathrm{Aa}$ & $34.95(1.62) \mathrm{Aa}$ & $34.10(3.10) \mathrm{Aa}$ & $33.61(2.53) \mathrm{Aa}$ & $33.25(2.38) \mathrm{Aa}$ \\
\hline & Listerine & 40.88 (1.85) Aa & 33.03 (3.02) Ab & $31.43(2.50) \mathrm{Ab}$ & 30.46 (3.62) Ab & $28.55(2.13) \mathrm{Ab}$ \\
\hline & Oral-B & 40.17 (1.83) Aa & 33.65 (1.49) Ab & 30.82 (1.99) Abc & 29.46 (1.84) Abc & $27.27(1.76) \mathrm{Ac}$ \\
\hline & Plax & 40.88 (1.89) Aa & $33.45(2.74) \mathrm{Ab}$ & $30.32(2.75) \mathrm{Ab}$ & 28.80 (2.67) Ab & $27.84(3.00) \mathrm{Ab}$ \\
\hline & Periogard & 40.84 (1.63) Aa & 35.07 (3.44) Aab & 32.35 (2.31) Ab & 30.74 (2.87) Ab & 29.75 (4.22) Ab \\
\hline
\end{tabular}

Means followed by the same uppercase letter in the column (comparison of each resin brand) and the same lowercase letter in the line does not differ to $5 \%$ level of significance $(\mathrm{P}<.05)$ in Tukey's test.

Table 5: Mean results (Standard Deviation) of Knoop hardness of indirect composite resins for mouthwashes

\begin{tabular}{|c|c|c|c|c|c|}
\hline Variation factors & $d f$ & SS & MS & $\mathbf{F}$ & $P$ \\
\hline Resin & 4 & 63207.62 & 15801.90 & 927.98 & $<0.001^{*}$ \\
\hline Bleaching agent & 3 & 11.59 & 3.86 & 0.23 & 0.878 \\
\hline Resin $\times$ bleaching agent & 12 & 323.24 & 26.94 & 1.58 & 0.100 \\
\hline Between samples & 180 & 3065.10 & 17.03 & & \\
\hline Period & 2 & 6830.67 & 3415.33 & 1390.49 & $<0.001^{*}$ \\
\hline Period $\times$ resin & 8 & 1231.81 & 153.98 & 62.69 & $<0.001^{*}$ \\
\hline Period $\times$ bleaching agent & 6 & 31.47 & 5.24 & 2.14 & $0.048^{*}$ \\
\hline Period $\times$ resin $\times$ bleaching agent & 24 & 288.73 & 12.03 & 4.90 & $<0.001^{*}$ \\
\hline Intra samples & 360 & 884.23 & 2.46 & & \\
\hline
\end{tabular}

${ }^{*} P<.05$ indicates statistically significant difference.

Table 6: Three-way repeated-measures analysis of variance (ANOVA) for bleaching agents.

The objective of a secondary polymerization is to maximize the degree of conversion of composites in order to improve mechanical and physical properties, durability, solvent resistance and biocompatibility [19]. The presence of non-polymerized monomer in the matrix affects the properties of composite materials and may induce surface degradation and discoloration [20]. Some studies showed improvement of some mechanical properties such as fracture toughness, flexural strength and hardness of composites when increasing the degree of conversion due to additional polymerization [10,19,21]. However, an improvement in the degree of conversion does not necessarily result in better mechanical properties because these are also related to other factors such as resin composition, filler content, particle size and distribution as was said in this study.

Due the difference in composition and curing method recommended by each manufacturer of indirect resins the degree of conversion can be affected. This can also explain the different values for initial hardness of the materials. Based on the investigation above, the characteristics of the material should be known to obtain a great durability of indirect composite restorations. The size and quantity of filler particles have a direct influence on the hardness of resins [22]. The increasing of the inorganic content on these composites prevents the plastic deformation in the organic matrix because it enhances the adhesion of filler particles to it, shortens the polymeric chains [23] and decreases water absorption [11] as observed in the current study since Cristobol has $74 \%$ of inorganic content [9]. Besides, composites with smaller particles are more resistant to wear because they are more homogenous and have less salient particles in their surface [22].

However, not only the filler particles have effect on the mechanical properties of indirect composite resins. According to Sideridou et al., the composition of the resins can also influence their mechanical characteristics [24]. The Sinfony resin has basically UDMA in its composition. This chemical compound increases the susceptibility of the resins to beverages solvents since it has molecules of $\mathrm{CO}$ and $\mathrm{NH}_{2}$ which are easily broken by water causing greater sorption of it. 


\begin{tabular}{|c|c|c|c|c|}
\hline \multirow{2}{*}{ Resin } & \multirow{2}{*}{ Bleaching } & \multicolumn{3}{|c|}{ Period } \\
\hline & & Initial & After 7 days & After 14 days \\
\hline \multirow[t]{4}{*}{ Adoro } & Saliva & $43.00(3.13) \mathrm{Aa}$ & $42.13(4.08) \mathrm{Aa}$ & $39.24(4.75) \mathrm{Aa}$ \\
\hline & Carbamide & $43,21(2.19) \mathrm{Aa}$ & $40.29(1.92) \mathrm{Aa}$ & $39.71(2.07) \mathrm{Aa}$ \\
\hline & 7.5\% Hydrogen & $43.36(2.81) \mathrm{Aa}$ & 39.75 (4.26) Aab & $38.36(4.32) \mathrm{Ab}$ \\
\hline & $38 \%$ Hydrogen & $44.39(2.00) \mathrm{Aa}$ & 40.49 (3.11) Aab & 36.41 (3.08) Ab \\
\hline \multirow[t]{4}{*}{ Resilab } & Saliva & $42.08(3.57) \mathrm{Aa}$ & 28.94 (3.50) Ab & 28.45 (4.48) Ab \\
\hline & Carbamide & $42.84(1.62) \mathrm{Aa}$ & 34.64 (3.79) Bb & $28.92(3.26) \mathrm{Ac}$ \\
\hline & 7.5\% Hydrogen & $44.88(2.41) \mathrm{Aa}$ & $35.14(4.80) \mathrm{Bb}$ & $28.46(1.95) \mathrm{Ac}$ \\
\hline & $38 \%$ Hydrogen & 42.91 (3.26) Aa & 34.86 (3.97) Bb & 31.39 (3.00) Ab \\
\hline \multirow[t]{4}{*}{ Cristobol } & Saliva & $48.82(1.97) \mathrm{Aa}$ & 46.07 (1.38) Aab & $43.83(1.41) \mathrm{Ab}$ \\
\hline & Carbamide & $48.04(0.84) \mathrm{Aa}$ & 42.54 (1.79) $\mathrm{Ab}$ & $40.73(1.70) \mathrm{Ab}$ \\
\hline & 7.5\% Hydrogen & 49.37 (3.94) Aa & 44.55 (2.11) Aab & $41.67(2.46) \mathrm{Ab}$ \\
\hline & $38 \%$ Hydrogen & $50.22(2.98) \mathrm{Aa}$ & $43.41(2.21) \mathrm{Ab}$ & $42.58(1.50) \mathrm{Ab}$ \\
\hline \multirow[t]{4}{*}{ Sinfony } & Saliva & 21.15 (3.79) Aa & 13.65 (3.98) Ab & $12.35(2.86) \mathrm{Ab}$ \\
\hline & Carbamide & 20.41 (1.91) Aa & 12.63 (2.90) Ab & $12.47(2.64) \mathrm{Ab}$ \\
\hline & 7.5\% Hydrogen & 20.97 (1.71) Aa & 12.83 (1.31) Ab & $12.32(0.99) \mathrm{Ab}$ \\
\hline & $38 \%$ Hydrogen & $20.67(2.38) \mathrm{Aa}$ & 12.70 (1.65) Ab & 11.34 (1.69) Ab \\
\hline \multirow[t]{4}{*}{ Epricord } & Saliva & $38.96(0.82) \mathrm{Aa}$ & 34.71 (1.60) Aab & $33.95(0.64) \mathrm{Ab}$ \\
\hline & Carbamide & $39.66(1.44) \mathrm{Aa}$ & $35.10(2.58) \mathrm{Aa}$ & $34.81(2.34) \mathrm{Aa}$ \\
\hline & 7.5\% Hydrogen & $39.46(0.85) \mathrm{Aa}$ & 34.42 (1.49) Ab & $34.38(1.13) \mathrm{Ab}$ \\
\hline & $38 \%$ Hydrogen & $39.96(2.43) \mathrm{Aa}$ & 35.29 (2.45) Aab & $34.66(1.91) \mathrm{Ab}$ \\
\hline
\end{tabular}

Means followed by the same uppercase letter in the column (comparison of each resin brand) and the same lowercase letter in the line does not differ to $5 \%$ level of significance $(P<.05)$ in Tukey's test.

Table 7: Mean results(Standard Deviation) of Knoop hardness of indirect composite resins for bleaching.

As Bagheri et al. affirmed, the water has the ability to penetrate the polymeric chains separating the filler particles of the matrix resin [25]. According to this statement, it can be observed that Resilab showed lower hardness results. This fact may be attributed to the hydrophilic monomers (TEGDMA) content in its composition which promotes great water absorption what may affect the resin hardness [26]. This uptake produces leaching of the ceramic filler particles of the resin matrix. Probably, it happens due to the breakdown of the silane bond between the resin and the filler particles [26]. This factor may have promoted the hardness reduction of Resilab and Sinfony since both have lower inorganic content, hydrophilic chemical compounds in the resin matrix and bigger particles than the others test indirect composite resins which facilitate the water incorporation into the polymeric chains and the leaching of filler particles with the course of time.

Even with all the considerations present in literature about the factors that can affect the mechanical properties of composite resins, the laboratory simulations in which the specimens are immersed in different storage medias have the bias of not including the effect of biofilm and real saliva [27]. Peutzfeldt et al. affirmed that the influence of mouthwashes can be modified clinically by many factors, for example, real saliva may neutralize the $\mathrm{pH}$ of these solutions reducing the softening of the resin and promoting a protective effect on its surface [19]. In the current study, the results are consistent with other studies that evaluated the hardness of indirect composite resins, demonstrating despite the bias of the methodology, the results have clinical correspondence to the resins performance $[11,28]$.

So, it can be verified that there were alterations in the hardness of the specimens after immersion in the different solutions. Cristobol and Sinfony presented the greater and lower hardness results, respectively. Furthermore, Resilab and Sinfony had the greater decreasing of hardness, confirming that the longevity of the indirect composite resins is directly linked with their composition. Only the mouthwashes significantly reduce the hardness of the specimens.

\section{Acknowledgement}

The authors thank the State of Sao Paulo Research Foundation (FAPESP) for the financial support (Process number No 2010/17496-0).

\section{References}

1. Duquia RCS, Osinaga PWR, Demarco FF, Habekost LV, Conceição EM (2006) Cervical Microleakage in MOD Restorations: In Vitro Comparison of Indirect and Direct Composite. Oper Dent 31: 682-687.

2. Samra APB, Pereira SK, Delgado LC, Borges CP (2008) Color stability evaluation of aesthetic restorative materials. Braz Oral Res 22: 205-210.

3. Powers JM, Fan PL (1980) Erosion of composite resins. J Dent Res 59: 815819

4. Schulze KA, Marshall SJ, Gansky SA, Marshall GW (2003) Color stability and hardness in dental composites after accelerated aging. Dent Mater 19: 612619

5. Zanin FR, Garcia LFR, Casemiro LA, Pires-de-Souza FCP (2008) Effect of artificial accelerated aging on color stability and surface roughness of indirect composites. Eur J Prosthodont Restor Dent 16: 10-14.

6. Leinfelder KF (2005) Indirect posterior composite resins. Compend Contin Educ Dent 26: 495-503.

7. Cesar PF, Miranda WG Jr, Braga RR (2001) Influence of shade and storage time on the flexural strength, flexural modulus, and hardness of composites used for indirect restorations. J Prosthet Dent 86: 289-296.

8. Nakamura T, Saito O, Mizuno M, Tanaka H (2002) Changes in translucency and color of particulate filler composite resins. Int J Prosthodont 15: 494-499.

9. Omata Y, Uno S, Nakaoki Y, Tanaka T, Sano H, et al. (2006) Staining of Hybrid Composites with Coffee, Oolong Tea, or Red Wine. Dent Mater J 25: 125-31.

10. Catelan A, Briso ALF, Sundfeld RH, dos Santos PH (2010) Effect of artificial aging on the roughness and microhardness of sealed composites. $\mathrm{J}$ Esthet Restor Dent 22: 324-330.

11. Borba M, Della Bona A, Cecchetti D (2009) Flexural strength and hardness of direct and indirect composites. Braz Oral Res 23: 5-10.

12. Faverani LP, Barão VA, Remalho-Ferreira G, Ferreira MB, Garcia-Júnior IR, et al. (2013) Effect of bleaching agents and soft drink on titanium surface topography.J Biomed Mater Res B Appl Biomater.

13. Jain V, Platt JA, Moore K, Spohr AM, Borges GA (2013) Color stability, gloss, and surface roughness of indirect composite resins. J Oral Sci 55: 9-15. 
Citation: dos Santos DM, Massurani L, Goiato MC, Zavanelli AC, Haddad MF, et al. (2014) Effect of Different Solutions on Knoop Hardness of Indirect Composite Resins. Dentistry 4: 208. doi:10.4172/2161-1122.1000208

14. Celik C, Yuzugullu B, Erkut S, Yamanel K (2008) Effects of mouth rinses on color stability of resin composites. Eur J Dent 2: 247-253.

15. Guler AU, Yilmaz F, Kulunk T, Guler E, Kurt S (2005) Effects of different drinks on stainability of resin composite provisional restorative materials. J Prosthet Dent 94: 118-124.

16. Barbosa CM, Sasaki RT, Flório FM, Basting RT (2009) Influence of in situ postbleaching times on resin composite shear bond strength to enamel and dentin. Am J Dent 22: 387-392.

17. Gurdal P, Güniz, Akdeniz B, HakanSen B (2002) The effects of mouthrinses on microhardness and colour stability of aesthetic restorative materials. J Oral Rehabil 29: 895-901.

18. Festuccia MS, Garcia Lda F, Cruvinel DR, Pires-De-Souza Fde C (2012) Color stability, surface roughness and microhardness of composites submitted to mouthrinsing action. J Appl Oral Sci 20: 200-205.

19. Peutzfeldt A, Asmussen E (2000) The effect of postcuring on quantity of remaining double bonds, mechanical properties, and in vitro wear of two resin composites. J Dent 28: 447-452.

20. Souza RO, Ozcan M, Michida SM, de Melo RM, Pavanelli CA et al. (2010) Conversion degree of indirect resin composites and effect of thermocycling on their physical properties. J Prosthodont 19: 218-225.
21. Ortengren $U$, Wellendorf $H$, Karlsson S, Ruyter IE (2001) Water sorption and solubility of dental composites and identification of monomers released in an aqueous environment. J Oral Rehabil 28: 1106-1115.

22. Sideridou I, Achilias DS, Kyrikou E (2004) Thermal expansion characteristics of light-cured dental resins and resin composites. Biomaterials 25: 3087-3097.

23. Gonçalves F, Kawano Y, Braga RR (2010) Contraction stress related to composite inorganic content. Dent Mater 26: 704-709.

24. Sideridou I, Tserki V, Papanastasiou G (2003) Study of water sorption, solubility and modulus of elasticity of light-cured dimethacrylate-based dental resins. Biomaterials 24: 655-665.

25. Bagheri R, Burrow MF, Tyas MJ (2007) Surface characteristics of aesthetic restorative materials: an SEM study. J Oral Rehabil 34: 68-76.

26. Drummond JL (2008) Degradation, fatigue, and failure of resin dental composite materials. J Dent Res 87: 710-719.

27. Bayne SC (2012) Correlation of clinical performance with 'in vitro tests' of restorative dental materials that use polymer-based matrices. Dent Mater 28 : $52-71$

28. Mandikos MN, McGivney GP, Davis E, Bush PJ, Carter JM (2010)A comparison of the wear resistance and hardness of indirect composite resins. J Prosthet Dent 85: 386-395. 